\title{
OFFICERS OF PRIVATE AND PUBLIC CORPORATIONS.
}

\author{
By D. T. WATSON,
} of the Pittsburgh Bar.

Among the advantages of the profession of the law, is the alluring nature of its studies and the keen satisfaction one takes, in following the decisions on any one question.

To start with the principle as it is first adjudged and then follow its developments, including its limitations, is a fascinating and delightful occupation. Case after case, shows the progress of the advancement, but every here and there, like worn soldiers on a march, we find some who have strayed to and laid down by the wayside. These exceptions, (in the law) are usually hard cases, where Judges, being human, do a little wrong to accomplish what then seems a great good, and like the decisions on the rule in Shelly's case, the exceptions sometimes so multiply as to beat out a new path. But in the great majority of cases these stragglers are few, and the cases are landmarks easily leading back over a more or less straight path to the first adjudged case.

As illustrating this and showing the beauty of the principle, the uniformity of decisions and the fascination of the occupation, let me refer to what the developments of the last thirty years have made an important question in America, and that is, the strongly marked features of the relation that exists between the numerous corporations of the day and their officers and directors.

From the nature of the occupation of the officers and directors of a corporation, the courts have held that such officer or director is an agent, and that his relation to his company is confidential and in the nature of a trust. From this it necessarily followed that such agent may not make secret gains for himself in the course of his agency out of his official position, or from the property of the corporation.

Now notice some of the developments of this principle. 
The rule was held to include all secret profits. The mere fact that in the course of his agency, and by reason thereof, and without the knowledge of his principal, the agent made money, was sufficient to impress that money with a trust and stamp it with the name of the company of which he was an officer or director. All schemes by which the officer or director indirectly shares in the gains of any transaction to which the principal, his employer, is a party, are alike faulty, no matter how well planned or how cunningly protected.

It is not a controlling question whether the principal makes or loses money in the transaction. The unbending rule that the agent cannot make secret gains in the course of and out of his agency is not alone based on results to the principal, but on the principal that the agent must act in the utmost good faith to his employer, and this good faith forbids him placing himself in a position where his individual interest might clash with his duty as agent. In equity all money over and above his salary which he receives by reason of such position, is so much paid for the office itself, which office is the property of the principal.

Even if it could be shown that in a given case the acts of the officer or director were distinctly beneficial to the corporation, yet this would not condone the agent's guilt if, in fact, he made secret profits out of his trust relation, nor would it enable such agent to retain such profits.

Two tests have been developed to determine whether the gains in any given case belong to the principal or the agent:

(I.) If the gains were secret and made by the agent in the course of and by reason of his agency, they belong to the principal and should be turned into the treasury of his employer.

(II.) If the gains were sceret and made by the agent out of the property of the principal, they likewise belong to the principal, and should be turned into its treasury.

One concerns all secret gains made by the agent in the course of and out of his agency. The other includes all secret gains made by the agent out of the property of his principal.

Given the facts in any case, the question is, was the gain made either out of the agency or out of the property? This reduces the investigation so that in each case two questions alone are of prime importance: (I) Was the gain secret? (II) Was it made out of the agency or out of the principal's property?

If a suitor establishes either of these two propositions, the Court has, most rigidly and consistently, refused to shield any one, but 
compelled the delinquent to account. It is even noticeable how often in the English cases the Court seems to make it a point to comment on the turpitude of the conduct where men of title and rank are the parties. In no branch of the law have the decisions been more consistent and determined.

A few of the English ones are as follows :

In the Madrid Bank v. Pelly (L. R.), 7 Equity Cases 44r, the articles of association authorized the directors of the bank to pay

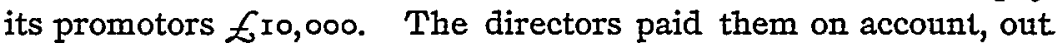
of the subscriptions for stock, $£ 5,000$, and as a present, and without any prior understanding, $£ 500$ were given by the promotors to four of the directors. Held, it was a gain made by the directors in the course of and out of their agency, and belonged to the bank.

In McKay's case, 2 Ch. D. I., the promotors gave, as a present, to the Secretary of the Company, six hundred (600) shares of the paid-up stock lawfully issued to the promotors. Held, it belonged to the corporation, the Court saying :

"All the remuneration which an Agent so receives he receives on behalf of his principal, and it does not matter whether it formed part of the original bargain or was a present as remuneration for services."

In Packer v. McKenna (L. R.), Io Chancery Appeal Cases, I r8, a bank sold to B a portion of its stock, to be paid for in instalments and delivered only as paid. Being unable to handle all of the stock, B sold a part of it, which was yet undelivered, to some of the directors of the bank, who resold the same at a profit. Feld, the profits were the property of the bank. The contract between $B$ and the bank was executory, and it was the duty of the directors to see that $B$ performed his part of the contract; that the directors, by their purchase from $B$, became interested with him and against the bank in the stock, and though no loss resulted to the bank, the directors could not keep the secret profit. Lord Cairnes said:

"All that the Court has to do is to examine whether a profit has been made by an agent without the knowledge of his prncipal in the course and execution. of his agency."

Money paid to an officer or trustee to induce him to retire from the position that a successor may be appointed is the property of the corporation or trust from which he retires. (Sugden. v. Cronland, 3 S. M. and Gifford rg2.)

These cases are fairly illustrative of the special tests suggested, 
but the doctrine itself of the confidential relations is still further applied.

It includes and covers all classes of dealings with the corporation by the officer or director whether induced by his confidential relation or not. In all dealings he must act in good faith, and his candor must be in proportion to the control and influence, he, as officer or director, has, to determine for the Company, its action upon the contract or thing proposed. If he, as such officer or director, has the ultimate determination for the corporation, his action is held to a most rigid investigation, and the validity of his acts would be determined by the sternest rules as to the morality of the transaction and freedom from selfishness.

This does not forbid all dealing by one who controls a corporation, with the corporation itself, but it does require, as a condition of all dealing, good faith on his part, and the burden of proof not infrequently is cast upon the agent to show it.

The rules of law governing the ordinary contract relations of life are not an exemplification of the golden rule.

Caveat emptor was not a moral deduction of the reason.

It, and like rules, recognize the selfishness which is said to be a necessity of evolution. The almost universal desire for gain is the fulcrum from which the world of commerce is moved, and though not universally, approximately, it is true, that where one man gains, some one else loses. All the artifices of trade which trench not upon fraud are open to each, where two men each, sui juris, contract. But this is not so where the officer or director sells to or buys from his own corporation. He may not deal with it at arms length. He must go a step further and deal openly.

The decisions in the Twin Lick Oil Company v. Marburry, 9I U. S. 587 , of the Supreme Court of the United States, and in Warner's Appeal, second Central Reporter 44, of the Supreme Court of Pennsylvania, consider and illustrate this distinction.

In Warner's Appeal the facts were that a state bank had closed its doors by order of its President in the absence of and without the knowledge of the directors. Subsequently the directors believing the bank could safely open, and to enable it to do so, loaned it $\$ 280,000$, and voted to themselves bills receivable to secure the payment of the loan. The bank re-opened, but after three days closed finally and made an assignment for the benefit of its creditors. The assignee filed a bill against the directors in which he set up, inter alia, that owing to this trust relation between them and the bank their action in taking the notes as security was illegal. 
Held, that as it was a transaction in good faith and intended, though mistakenly so, to benefit the bank, the directors could lawfully retain possession of the bills receivable until the loans were paid.

In the Northwestern Transportation Company $v$. Beatty, 12 Appeal Cases 589, the majority stockholder in a corporation sold to it a ship and though the purchase was opposed by some of the stockholders, he carried it through by means of his holdings of stock. Thus, in a limited sense, he was the vendor and vendee. Yet on a final appeal to the House of Lords the contract was sustained.

In Gloniger v. The B. \& O. Ry. Co., r 39 Pa. St. r3, a mortgage, from one corporation, in a system of railroads, voted to itself, by another corporation owning a majority of the stock was held valid.

Coming within these confidential relations, are the cases where the officer or director sells to his corporation, a property in which he has a private interest, without disclosing fully such interest. There the contract of sale is held voidable, and the corporation on discovering the facts may affirm it or rescind it.

The relation itself is utterly inconsistent with secrecy, and the agent who would sell to his Company must do so in the broad light of day.

His disclosure must be full. It will not do to merely tell that he is interested or has an interest. He must go further, and tell. the extent and nature of the interest.

This is well illustrated in the case of The Imperial Mercantile Credit Association ( L. R.), 6 Chancery Appeal Cases 567, where a director who was a broker offered to the Association certain bonds at a figure which netted him a profit. When he offered them he said he had an interest in the sale but did not tell the extent of his interest. The lower court thought the disclosures sufficient but on appeal the decree was reversed and the rule was stated as requiring the utmost candor, and this was not complied with where the actual profit to the director was not disclosed.

It is important to observe that under the first class of cases where a secret profit is made out of the agent's position or out of the Company's property, this money is held to belong to the Company. It is just so much money that should have gone into the treasury of the Company but which the agent wrongfully kept. He is a trustee for the Company, of the money, and no. question of recission arises. 
But, where the property in which the Company had theretofore no interest is sold to the Company, and the Company in actual possession of the property discovers that the vendor was really one of the directors or officers, this information enables the corporation to do one of two things - either to rescind or affirm the contract. If it rescinds, a return of the property is indispensable to relief, because the corporation cannot keep the property it acquired by means of the contract and refuse on its part to comply with the contract.

Thus in the Great Luxembourg Railway Company v. Sir William Magnay, 25 Bevan 592, a foreign concession was offered to and bought by the Railway Company at a meeting of its shareholders duly held, but such shareholders did not know that Sir William, the President of the Railway Company, was the principal owner of the thing sold, nor did he disclose such interest.

Held, that when the shareholders discovered the fact it was optional with them to rescind, but as after discovering this fact the Shareholders sold the concession to a third party, this prevented a recission by the act of the Company, and the bill against Sir William was dismissed.

In such class of cases the Company that would undo the transaction must offer to restore to its vendor the property he sold it.

As a part of this rule the Courts have required it to commence suit within a reasonable time, and what this is depends upon all the circumstances of each case.

The following delays have been held unreasonable:

In Graham v. Birkenhead Co., 2 Mac. \& G. $x_{46}$-eighteen months; in Kitchen v. St. Louis Ry. Co., 69 Missouri 224-two years; In Re Magdalena Co., 6 Jurist (N. S.) 975 - two years; in the Great Western Co. $v$. Oxford Co., 3 DeG. M. \& G. 34Ieight months. See also Dentfell v. O. \& M. Ry. Co., Iıо U. S. 209 .

To make these rules of real use and not merely theoretical, the Courts held that though it is true the corporation is the party who must sue, as the wrong is to it, yet if the corporation will not, any one of the stockholders may bring suit. But still dealing justly with all interests it, was also held, that one stockholder could not involve his Company in litigation if the majority of the stockholders were opposed to such action, and, therefore, prior to the 
suit the stockholder must present his request to the governing board, usually the directors, asking them, in the name of the Company, to institute suit to recover the money thus wrongfully withheld from the Company, and, if the board wrongfully refuses so to do, he may then file a stockholder's bill making the Company and the delinquent officer parties. He must aver that such request was made, in good faith, and was wrongfully refused, and in some cases, he must also show an attempt on his part to summon a meeting of the stockholders, and have action taken by them before a bill can be filed.

The limitation of the rule, and the rule itself, will be found fully stated in the following cases: Hawes $v$. Oakland, ro4 U. S. 456; Brewer v. Boston Theatre, ro4 Mass. 378; Gamble v. Queens County Water Co., I23 New York 9r; Foss v. Harbottle, 2 Hare 461.

Care should be taken that the bill be filed in the name of a stockholder who is not personally disqualified from acting, for, as he becomes the complainant, a defense personal to him will defeat the suit. (Burt v. British Life Association, 4 DeGex \& J. I73.)

If official position in large corporations and in public life are too often used to enable the occupants to reap where they have not sown, and grow rich out of money which, in good faith, belongs to the State or the private corporation, a Court of Chancery affords ample means of relief.

No position, however subtle, will avail as a defense, if it once be shown that these profits are secret and were made out of the Company's property, or by the agent in the course of his agency.

In no class of cases is a Court more strict in its search for traces of bad faith and more exact in requiring the agent to show the perfect good faith of the transaction. Evasion or want of frankness on his part is likely to be fatal, even if unintentional.

All profits made by officers of a State, City or County out of the public funds in their possession, or over which they have control, are the property of the State, City or County. This includes not merely money paid by banks or others, for the use of such funds, but all gain from speculation by means of the same.

So, in all the ramifications which human ingenuity has devised by which officers of a corporation may make individual secret gains, these gains are the property of the Company. Let the officer lay his plans ever so covertly they can avail him noth- 
ing. The very ingenuity is proof of his bad faith. If he lets or aids in letting contracts for fast freight or express to a firm or corporation of which he is, in some indirect way, the beneficiary, this money belongs to the Company. If the contracts for coal or any other necessity of the Company are let so as to benefit him; if he grants transportation facilities for shipment of coal or other freight at more favored rates than the shipper would have received if the officer had not been benefited by these rates, this gain of the officer is so much money of the Company.

Indeed, the shipper, who, by the division with and influence of the officers or directors, receives what is equivalent to money of the corporation, knows that he is receiving this unlawfully, and the corporation may, by an action brought, recover the money.

Thus, where an oil broker assisted the president of a bank in a speculation in o1l, and this broker knew that the money used in the speculation was that of the bank; he was held individually liable for all the money thus used, and that on a bill filed by the assignee of the bank. (Warner v. McMullen, $x_{3}$ Pa. St. 378.)

Look back now and see even from this brief review how easy and natural has been the development from the principle of the confidential relation that exists between the officer and the corporation. See how broad and well marked are the lines of its development, and see how well the cases fall within those lines. No code or system of law or equity, of which we have any knowledge, ever held more sacred such relations of life than ours, and seldom has there been cause to complain that the courts have allowed the guilty one to escape.

The enunciation of this principle, the stern adherence to it, the consistent development of it, and the limitation to render it efficient only, and not an engine of oppression, is worthy of the highest praise. 